\title{
Formation of plant tracheary elements in vitro - a review
}

\author{
Christine Devillard ${ }^{1}$ and Christian Walter ${ }^{2^{*}}$
}

\begin{abstract}
This review summarises two key aspects of in vitro plant tracheary element (TE) culture systems: establishment of in vitro TE systems and methods for analysing TEs, based on examples of in vitro TE systems in angiosperms and gymnosperms. A comparison between different TE systems suitable for various species and recent research studies are also presented along with a presentation of the issues and future challenges underlying in vitro TE systems.
\end{abstract}

Keywords: Cell differentiation; in vitro; Lignification; Plant cell; Programmed cell death; Secondary cell wall; Tracheary element; Wood; Cylogenesis

\section{Review}

Trees are major components of the biosphere and their wood plays a crucial role as a sustainable and renewable primary product. Wood is one of the most widely utilised natural materials on earth. The world currently consumes 3.4 billion $\mathrm{m}^{3}$ of wood per year (Fenning et al. 2008). Projections generated using a global forest-products model suggest that the value of global consumption of wood products will increase - in real terms - at 1.9\% per annum from US\$597 billion in 2002 to US\$ 1,023 billion in 2030 (Turner et al. 2006). This increase is based on continued use of wood as raw material for fuel, pulp, paper and timber production, and the manufacture of secondary wood products. Woody biomass is also expected to be utilised as a sustainable and carbon-neutral resource for biofuel and biomaterial products. It is a cost-effective and renewable resource for industry and energy demands. The understanding of the underlying processes of wood formation (xylogenesis) is imperative for improving the quantity and quality of wood produced considering the important roles of wood currently and in the future (Bollhöner et al. 2012; Oda and Fukuda 2012; Fukuda 2010; Turner et al. 2007).

\section{What are tracheary elements?}

Wood (xylem) and phloem are derived from cambial cells and are produced by the secondary vascular system of plants. In planta, the formation of secondary xylem is

\footnotetext{
* Correspondence: chris.walter@paradise.net.nz

${ }^{2} 12$ Calder Road Lake Okareka, Rotorua 3076, New Zealand

Full list of author information is available at the end of the article
}

a well-ordered developmental process that occurs under strict temporal and spatial regulation. It begins with cambial cell divisions and ends with the formation of xylem through programmed cell death (PCD).

Xylem tissues consist of three types of cells: tracheary elements (TEs), xylem parenchyma cells, and xylem fibre cells (Figure 1). The tracheary elements of angiosperm xylem (but not gymnosperm xylem) contain water-conducting cell types called vessels.Tracheary elements (TEs) are one of the major cell types in wood-forming xylem. They are water-conducting tubes that are responsible for distributing raw sap throughout the plant body. Mature TEs are dead cells. These specialised vascular cells form hollow tubes kept rigid and open by thickened ribs of secondary cell wall that provide the major structural element in wood. These lignified thickenings have a reticulate, spiral, annular, scalariform, or pitted pattern, which is one of their most characteristic morphological features (Fukuda 1992; Höfte 2010). The patterned deposits of secondary wall in TEs primarily consist of polysaccharides (cellulose microfibrils and hemicelluloses) and lignin, a complex aromatic polymer (Turner et al. 2007; Wagner et al. 2012). These cell wall components result in a structure of great strength and resistance to degradation (Lacayo et al. 2010). Deposition of cell wall polymers prevents the collapse of the xylem under the high pressure created by fluid transport (Roberts and McCann 2000; Fukuda 2004) and reinforces these cells enabling the TEs to withstand the negative pressure generated during transpiration. 


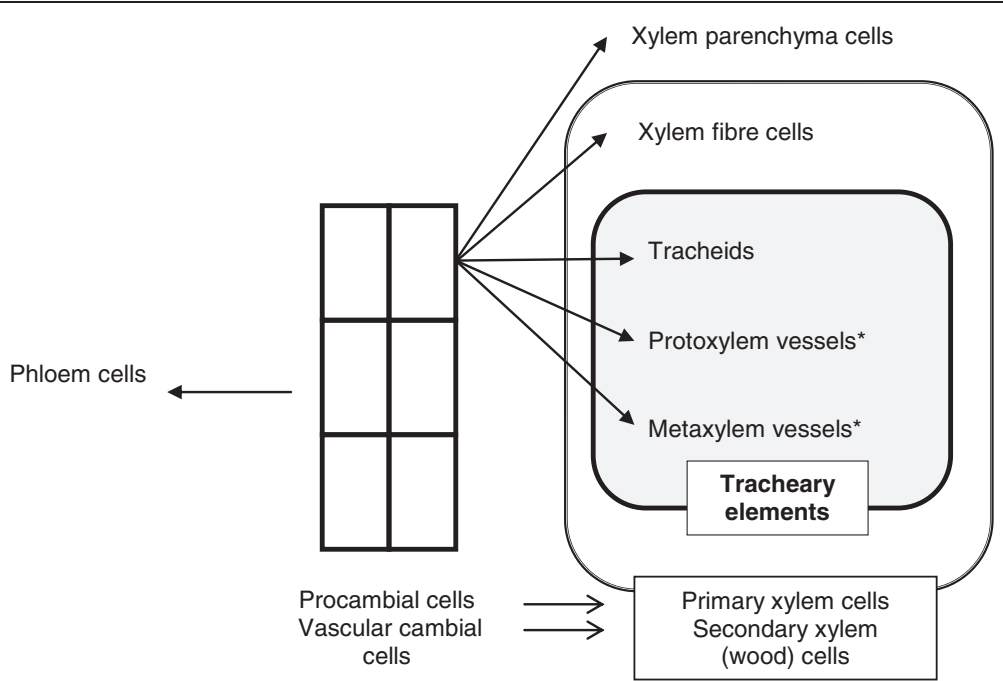

Figure 1 Schematic model of xylem and phloem formation showing the origin of tracheary elements, adapted from Demura \& Fukuda (2007). * Gymnosperms do not have vessels in their xylem (wood).

The advantages of studying tracheary elements in vitro A sequence of specific cellular events involving cell differentiation is required to form a mature TE and the study of this process in planta is difficult because differentiation occurs within complex tissues in the plant body. For example, TEs developing in planta are not easily accessible during secondary-xylem formation. Cells grown in vitro are more accessible for study of the developmental processes associated with xylogenesis. For example, cell cultures that differentiate a high percentage of TEs can be collected at different time points after induction of TE differentiation, and the changes in cell-wall biochemistry, gene expression, and the proteome or metabolome can be investigated (Milioni et al. 2002; Kubo et al. 2005; Demura et al. 2002; Möller et al. 2005a, 2005b). Ideally this will involve in vitro cell cultures that produce TEs in a synchronous manner to provide access to high percentages of TEs that are in specific stages of development. Examples of successfully established in vitro TE systems include Zinnia elegans L. or Arabidopsis thaliana L. These model systems have been instrumental in obtaining an improved understanding of cell wall architecture, composition and molecular organisation of cell walls in TEs (Lacayo et al. 2010; Höfte 2010; Oda and Fukuda 2012).

Experimental steps to induce tracheary elements in vitro The successive experimental steps of TE formation in vitro are: (i) initiation of xylogenic cell cultures, (ii) maintenance of cultures and (iii) differentiation of TEs.

\section{Initiation}

Initiation of xylogenic cell cultures can be performed using various types of explants from different plant species. Xylogenic cells are cultivated either on solid or in liquid medium with or without plant growth regulators. In vitro TE differentiation firstly requires the dedifferentiation of cells and subsequent differentiation of such cells into immature and finally mature TEs (Figure 2).

\section{Maintenance}

Maintenance of xylogenic cell cultures by regular transfers to fresh culture media is not possible for all initiated TE systems, although it has been demonstrated for several species. For example, initiation of Zinnia elegans xylogenic cell cultures is done exclusively from freshly isolated mesophyll cells as the subsequent maintenance of these has not yet been demonstrated. On the other hand, long-term maintenance of xylogenic cell cultures has been established for Pinus radiata D.Don (Möller et al. 2003), Arabidopsis thaliana (Oda et al. 2005; Pesquet et al. 2010) and hybrid poplar (Populus tremula L. $\mathrm{x}$ P. tremuloides Michx.) (Ohlsson et al. 2006).

\section{Differentiation}

Differentiation of TEs can be induced under controlled culture conditions from callus grown on solid medium or as cell suspension cultures (Table 1). This process has been studied using many different plant species (Fukuda and Komamine 1982; Fukuda 1992; Leitch and Savidge 2000; McCann 1997; Fukuda 1996) and is controlled by various factors (for review see Möller 2006). Trachearyelement differentiation is characterised by a series of cytological changes. Initial cell expansion is followed by deposition of lignified secondary cell wall and ultimately programmed cell death (PCD) (Fukuda 1996, 1997b, 2010; McCann 1997), the latter including autolysis of the cellular contents (Denton et al. 2012; Kuriyama and 


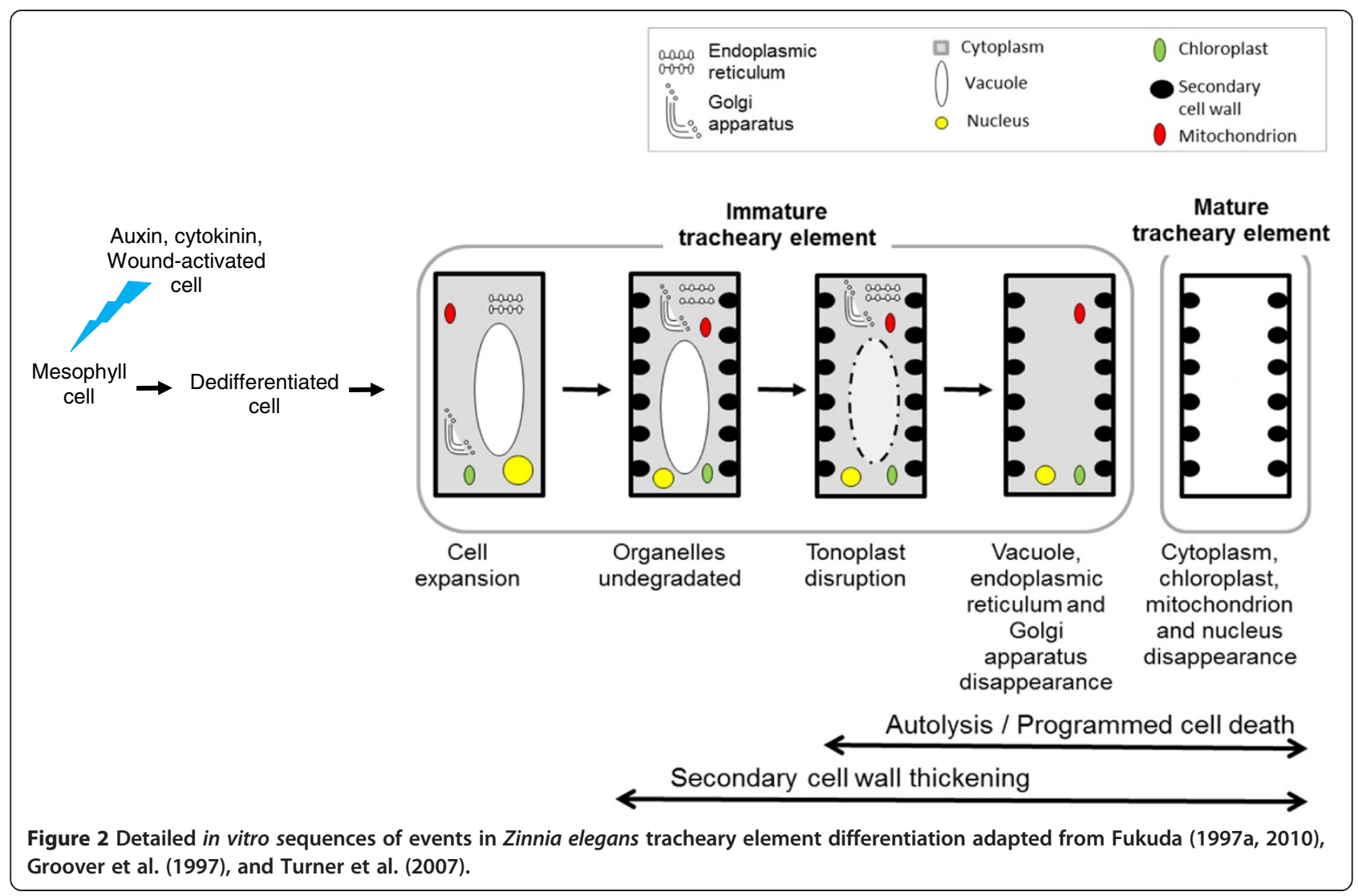

Fukuda 2002). The uniformity, accessibility and reduced complexity of in vitro cell cultures make them ideal research tools to investigate the regulation of PCD in plants (McCabe and Leaver 2000). Programmed cell death, the final process of TE differentiation, is a genetically regulated cell process that occurs in various developmental processes in plants. Programmed cell death is initiated by vacuole rupture. The release into the cytosol of hydrolytic enzymes, including deoxyribonucleases (DNases), ribonucleases (RNases) and proteases, leads to the degradation of TE cell contents (Groover et al. 1997; Obara et al. 2001; Fukuda 2000; Hara-Nishimura and Hatsugai 2011; Fukuda 1997a). The secondary cell-wall patterning during xylem differentiation and the regulation and function of xylem cell death have been reviewed by Oda and Fukuda (2012) and Bollhöner et al. (2012) respectively. Pesquet et al. (2013) demonstrated that cell death of maturing TEs occurs independently of their lignification status in $Z$. elegans xylogenic cell cultures, showing that lignification is neither an inducer nor a prerequisite for TE PCD. Furthermore, the authors showed that preventing cell death of maturing TEs inhibits TE cell wall lignification.

The time required for TE induction and differentiation varies among systems (Table 1). Differentiation rates for TEs vary between genotypes of the same plant species and between different species depending on the type of in vitro method used to induce TEs (Table 1). Synchrony of TE differentiation varies from fully synchronous (Fukuda and Komamine 1982; Pesquet et al. 2010), asynchronous (Möller et al. 2003) to over semi-synchronous (McCann et al. 2000; Pesquet and Tuominen 2011).

\section{Analysis of tracheary elements}

The composition, structure, and relative abundance of TEs can be investigated using a range of qualitative and quantitative methods. For example, morphological, cytological and histochemical analyses of differentiating TE cells can be performed to identify potential factors involved in TE differentiation. The three most common types of analysis are discussed in more detail below and summarised in Table 2.

\section{Microscopic analysis of tracheary elements}

Cytological characterisation of TE differentiation occurring in vitro can be done using microscopic analysis. Observation of secondary wall thickening under a light microscope allows TEs to be easily detected (Sato et al. 2011). Tracheary elements can be analysed qualitatively using morphological features and quantitatively by determining the rate of differentiation using cell counting 
Table 1 In vitro culture techniques, induction treatment duration and percentage of tracheary elements in various angiosperms and gymnosperms species

\begin{tabular}{|c|c|c|c|c|}
\hline Plant species & $\begin{array}{l}\text { In vitro culture } \\
\text { technique }\end{array}$ & $\begin{array}{l}\text { Percentage or } \\
\text { mean TEs } \\
\text { cell count* }\end{array}$ & $\begin{array}{l}\text { Duration } \\
\text { on induction } \\
\text { medium }\end{array}$ & References \\
\hline \multirow[t]{2}{*}{ Arabidopsis thaliana (A) } & Cell suspension & $30 \%$ & 4 days & Oda et al. (2005) \\
\hline & Cell suspension & $40 \%$ & Not reported & Pesquet et al. (2010) \\
\hline Cryptomeria japonica (G) & Callus & 2 to $34 \%$ & Not reported & Mehra \& Anand (1979) \\
\hline Cupressus sempervirens (G) & Callus & $30^{*}$ & Not reported & Havel et al. (1997) \\
\hline Daucus carota (A) & Callus & 0 to $56^{*}$ & 21 days & Aloni (1980) \\
\hline Glycine max var. Biloxi (A) & Callus & 0 to $9 \%$ & 21 days & Fosket \& Torrey (1969) \\
\hline Glycine max $(A)$ & Callus & 0 to $93^{*}$ & 21 days & Aloni (1980) \\
\hline Pinus contorta (G) & Cell suspension & 5 to $40 \%$ & Not reported & Webb (1981) \\
\hline Pinus radiata $(\mathrm{G})$ & Callus & 2 to $45 \%$ & 10 days & Möller et al. (2006) \\
\hline Pinus sylvestris (G) & Cell suspension & $16 \%$ & 25 days & Ramsden \& Northcote (1987) \\
\hline Populus tremula $\times$ P. tremuloides $(\mathrm{A})$ & Cell suspension & Occurrence & 9 to 30 days & Ohlsson et al. (2006) \\
\hline Pseudostuga menziesii (G) & Cell suspension & $65 \%$ & 42 to 49 days & Pillai et al. (2011) \\
\hline Syringa vulgaris (A) & Callus & 0 to $36^{*}$ & 21 days & Aloni (1980) \\
\hline \multirow[t]{7}{*}{ Zinnia elegans (A) } & Cell suspension & $30 \%$ & 3 days & Fukuda \& Komamine (1980b) \\
\hline & Cell suspension & $40 \%$ & 4 days & Fukuda \& Komamine (1982) \\
\hline & Cell suspension & $45 \%$ & 5 days & Gabaldón et al. (2005) \\
\hline & Cell suspension & $60 \%$ & 3 days & Fukuda \& Komamine (1980a) \\
\hline & Cell suspension & 50 to $65 \%$ & 3 days & Church \& Galston (1988) \\
\hline & Cell suspension & $76 \%$ & 2 days & Twumasi et al. (2009) \\
\hline & Cell suspension & $80 \%$ & 4 days & Roberts \& McCann (2000) \\
\hline
\end{tabular}

Abbreviations: $A$ angiosperm; $G$ gymnosperm. *: mean number per callus observed.

methodologies. Examples of the types of data that can be obtained using such methods are provided in Table 1.

Cells can be counted using a haemocytometer under either normal light or polarised light. Clumps of cells are usually observed when callus is used as in vitro source of xylogenic cells. Pillai et al. (2011) segregated clumps of cells using a ground glass grinder followed by filtration on a nylon mesh prior to microscopic observations of Pseudostuga menziesii (Mirb.) Franco TEs. Tracheary elements can be distinguished from other cell types under polarised light because the cellulose deposited in the reticulate cellwall thickenings produces strong birefringence.

Cell-staining techniques are very useful tools for cytological studies. Cell viability can be assessed following staining with Evans blue, 4',6-diamidino-2-phenylindole (DAPI), or fluorescein diacetate (FDA) staining (Groover et al. 1997). Evans blue is an indicator for non-viable cells while DAPI or FDA staining can be performed to differentiate between still living, differentiating TEs and dead TEs (Kärkönen et al. (2011).

Cell-wall components can also be visualised by selective staining. Phloroglucinol staining can be used to monitor the level of lignification (McCann 1997; Sato et al. 2011). Safranin also reacts with lignin by staining it red. Lignified secondary plant cell walls can also be visualised by staining them blue using $O$-toluidine blue. Cellulose can be localised in cell walls after staining with calcofluor white (Pesquet and Tuominen 2011). Fluorescence microscopy can be used to detect crystalline cellulose by labelling TEs with CtCBM3-GFP (green fluorescent protein), a fluorescently labelled family- 3 carbohydrate binding module that binds to cellulose (Lacayo et al. 2010). Lignin can be localised under a fluorescence microscope, due to autofluorescence of lignin in the green excitation range. Cell-wall polysaccharides can be analysed using fluorescence microscopy after labelling with a green fluorescent protein-tagged carbohydrate-binding molecule specific for cellulose (Lacayo et al. 2010). Cell-wall monosaccharide composition can be determined after hydrolysis and gas chromatography analysis (Möller et al. 2003). It is also possible to study the development of TEs in real time using time-lapse video microscopy (Groover et al. 1997). Pesquet et al. used time-lapse imaging of living cells to monitor TE programmed cell death 
Table 2 Microscopic, biochemical, and molecular analysis methods used with in vitro tracheary elements

\begin{tabular}{l} 
Analysis methods \\
\hline Microscopic analysis \\
Bright field microscopy \\
TE observation under light and \\
polarised light \\
TEs secondary wall fragments \\
generated by mild sonication \\
Cell counting under light and \\
polarised light \\
Evans blue staining \\
Phloroglucinol-HCl, safranin, \\
O-toluidine blue staining \\
Atomic force microscopy
\end{tabular}

Time-lapse microscopy and analysis

Fluorescence microscopy

Calcofluor white staining

DAPI, FDA viability staining

Lignin autofluorescence

Green fluorescent protein specific for crystalline cellulose

Flow cytometry cell sorting

Biochemical analysis

2D-NMR spectroscopy

AcBr lignin assay

Alkaline-nitrobenzene oxidation

Pyrolysis-GC-MS and FTIR

spectroscopy

FTIR spectromicroscopy

Klason lignin

Lignothioglycolic acid assay

NMR spectroscopy

TFA hydrolysis and GC/GC-MS

Thioacidolysis

Thioglycolic acid lignin assay

Molecular investigation

RT-PCR expression analysis

RNA-dependent gene overexpression or silencing (RNA interference)

\section{Research topic}

Selected references

TE morphological analysis

Internal organisation of TEs

Quantitative analysis of TEs

Localisation of non-viable cells

Lignin localisation

Topography of TE cell walls

Monitoring of TE PCD and cell wall synthesis

Cellulosic secondary cell walls observation

Localisation of living (non-lignified) cells

Visualisation of TEs lignified cell walls

Cellulose accessibility and binding in TEs

Separation of TEs from mesophyll cells

Lignin qualitative analysis

Lignin quantitative analysis

Monomeric composition of lignin

Lignin qualitative analysis

Polysaccharides qualitative analysis

Lignin qualitative analysis

Lignin content in differentiated cell wall

Polysaccharides qualitative analysis

Monosaccharide content in differentiated cell wall

Lignin qualitative analysis

Lignin quantitative analysis

Gene expression analysis

Gene function analysis
Pesquet and Tuominen (2011); Pillai et al. (2011)

Lacayo et al. (2010)

Kärkönen et al. (2011); Pesquet and Tuominen (2011)

Groover et al. (1997)

McCann (1997); Oda et al. (2005); Pillai et al. (2011); Sato et al. (2011)

Lacayo et al. (2010)

Groover et al. (1997); Pesquet et al. (2010)

Pesquet and Tuominen (2011)

Groover et al. (1997); Pesquet and Tuominen (2011)

Pesquet and Tuominen (2011)

Lacayo et al. (2010)

Ito et al. (2004); Weir et al. (2005)

Wagner et al. (2007)

Wagner et al. (2007)

Sato et al. (2011)

Pillai et al. (2011)

Lacayo et al. (2010)

Möller et al. (2005b)

Pillai et al. (2011)

Ramsden and Northcote (1987)

Pillai et al. (2011); Möller et al. (2003)

Möller et al. (2005a)

Möller et al. (2003)

Pesquet et al. (2010, 2013); Wagner et al. (2009); Milioni et al. (2002)

Pesquet et al. (2010); Endo et al. (2008); Endo et al. (2009); Möller et al. (2005b); Wagner et al. (2013); Wagner et al. (2009); Wagner et al. (2007) 
and cell wall synthesis in Arabidopsis thaliana wood cells (Pesquet et al. 2010).

Atomic force microscopy (AFM) has been used to reveal the topography of TE cell walls (Lacayo et al. 2010). Mild sonication was used to physically dissect TEs prior to microscopic analysis. The secondary cell-wall fragments generated provided direct access to the organisation of the internal secondary wall (Lacayo et al. 2010).

\section{Biochemical analysis of tracheary elements}

Separate TEs from non-differentiated cells is important for biochemical analysis and also for functional testing of genes involved in secondary cell wall formation, because changes in secondary cell wall composition can be detected more readily when the interfering primary cell walls of the other cell types present in the cultures, are removed.

Existing protocols for Pinus radiata enrich fully differentiated TEs by differential sedimentation (Möller et al. 2005b). Lacayo et al. (2010) used density-gradient centrifugation to separate mixtures of TEs, mesophyll, and dead cells after differentiation of cultured Zinnia elegans mesophyll cells. Fractions highly enriched in TEs were obtained using this physical process. Alternatively, mesophyll cells can be separated from TEs by flow cytometry involving the use of exogenous fluorescent labels (Weir et al. 2005).

Various qualitative and quantitative methods exist that can be used to analyse lignin. These include: a thioglycolic acid lignin assay (Möller et al. 2003); Klason lignin analysis (Möller et al. 2005b); thioacidolysis (Möller et al. 2005a, 2005b; Wagner et al. 2013); two dimensional nuclear magnetic resonance (Wagner et al. 2007); an acetyl bromide lignin assay (Wagner et al. 2007); alkalinenitrobenzene oxidation (Sato et al. 2011); pyrolysis-gas chromatography coupled mass spectroscopy (Pillai et al. 2011); and Fourier-transform infrared (FTIR) spectroscopy (Pillai et al. 2011). In some cases, similar methods are applicable to the analysis of cell-wall polysaccharides, e.g. nuclear magnetic resonance spectroscopy (Ramsden and Northcote 1987), or using trifluoroacetic acid hydrolysis followed either by gas chromatography (Möller et al. 2003) or by gas chromatography coupled mass spectroscopy (Pillai et al. 2011). Lacayo et al. (2010) generated an architectural model of Zinnia elegans TEs using biochemical extraction and three imaging platforms (atomic force microscopy, synchrotron radiation-based Fouriertransform infrared and fluorescence microscopy).

\section{Molecular analysis of tracheary elements}

Yamamoto et al. (1997) reported that uniconazole, an inhibitor of brassinosteroid synthesis, specifically suppressed the accumulation of transcripts for genes that were induced in the final stage of differentiation in association with secondary wall formation and cell death in cultured cells of Zinnia elegans. Yamamoto et al. (2007) isolated Zinnia genes to obtain the key enzymes of brassinosteroid synthesis in order to identify the molecular basis of the regulation of brassinosteroids synthesis. The results suggested that brassinosteroids biosynthesis during TE differentiation may be regulated by the coordinated regulation of biosynthesis of sterols and brassinosteroids. The team of Ito and Fukuda (2002) demonstrated that an S1-type nuclease, Zinnia endonuclease 1, is a central DNase responsible for nuclear DNA degradation during programmed cell death of Zinnia TEs. Later, Ito et al. (2006) reported that a dodeca-CLE peptide suppresses Zinnia TE differentiation. Ribo-nucleic acid silencing in Zinnia TE differentiating cell cultures was developed in 2008 (Endo et al. 2008). This method was used to identify the role of TE differentiation-related 6 (TED6) and TED7 genes in secondary cell wall formation in cultured Zinnia cells (Endo et al. 2009). Tracheary element differentiation increased with co-overexpression of TED6 and TED7. Pesquet et al. (2010) identified a key protein involved in the organisation of microtubules during TE differentiation using RT-PCR expression analysis, RNA-dependent gene overexpression and RNA-dependent gene silencing.

Lignification and lignin manipulations performed with angiosperms and conifers have been reviewed by Boerjan et al. (2003) and Wagner et al. (2012) respectively. Sato et al. (1997) isolated and characterised a novel peroxidase gene, $\mathrm{ZPO}-\mathrm{C}$, whose expression and function are closely associated with lignification during Zinnia TE differentiation. Pinus radiata xylogenic cultures were used to investigate the function of xylogenesis-related genes in conifers. Möller et al. (2005b) reported the silencing of cinnamyl alcohol dehydrogenase, an enzyme associated with the formation of cell wall polymers such as lignin, using RNA interference. Suppression of genes associated with the monolignol pathway in pine, such as $4 \mathrm{CL}$ and HCT (encoding 4-coumarate CoA ligase and $p$-hydroxycinnamoyl-CoA shikimate hydroxycinnamoyltransferase), resulted in substantial lignin reductions of up to 50-60\% (Wagner et al. 2007; Wagner et al. 2009). Suppression of a putative Pinus radiata clone (PrCCoAOMT) encoding the lignin-related enzyme caffeoyl CoA 3-O-methyltransferase (CCoAOMT) caused a reduction in lignin content of $5-20 \%$ in Pinus radiata TE cultures. The lignin composition was affected, which resulted in a lignin polymer containing $p$-hydroxyphenyl, catechyl and guaiacyl units (Wagner et al. 2011). Suppression of the lignin-related gene cinnamoyl-CoA reductase $(C C R)$ in Pinus radiata TEs resulted in up to $46 \%$ reduction in lignin content in CCR-RNAi lines (Wagner et al. 2013). 


\section{In vitro tracheary element systems in angiosperms and gymnosperms}

In vitro $\mathrm{TE}$ systems have been developed from both angiosperm and gymnosperm species but the majority of studies have focused on angiosperms. A summary of in vitro TE systems developed in herbaceous angiosperm species (particularly Arabidopsis thaliana and Zinnia elegans) and in wood-forming angiosperm and gymnosperm species is presented below.

\section{In vitro tracheary element systems in herbaceous angiosperms}

\section{The Arabidopsis thaliana xylogenic cell culture system}

Arabidopsis thaliana provides a good model for investigating the development of secondary xylem (Turner et al. 2007). Its short generation cycle and very small genome size enables a wide range of molecular and genetic approaches. Arabidopsis thaliana is one of the best genetically characterised plants with a genome size of $1.25 \times 10^{8}$ base pairs (The Arabidopsis Genome Initiative 2000) (Pillai et al. 2011). In comparison, the size of Pinus radiata genome is much larger $\left(2.6 \times 10^{10}\right.$ base pairs) (Ahuja and Neale 2005).

A xylogenic cell culture from Arabidopsis thaliana roots was established in vitro (Pesquet et al. 2010). New cell lines from root calli, were able to grow on hormone-free solid medium. Subsequently, calli were transferred to liquid medium and the cell suspensions transferred weekly to fresh medium. In this system, TE induction was triggered by addition of auxin, cytokinin, and brassinosteroid hormones. Single cells differentiated synchronously into TEs with up to $40 \%$ efficiency of TE differentiation (Table 1). The overexpression of the microtubule-associated protein gene (MAP70-1) enhanced the efficiency of TE differentiation up to $60 \%$. Pesquet et al. established that the microtubule-associated protein MAP70-5 is up-regulated during the secondary cell-wall formation of $A$. thaliana TEs (Pesquet et al. 2010; Pesquet et al. 2011). Microtubuleassociated protein MAP70-5 and its binding partner MAP70-1are essential for the normal banding pattern of secondary cell wall in A. thaliana wood-forming cells and for the proper development of xylem tissue. Furthermore, lignification of TEs was suggested to be due to either the oxidative burst associated with cell death or the lysis of their protoplast.

Secondary wall formation has been intensively studied during xylem cell differentiation. Recently, several NAM/ ATAF/CUC (NAC) domain protein transcription factors were shown to play crucial roles in specification into distinct xylem cells (Kubo et al. 2005, Demura and Fukuda, 2007; Yamaguchi and Demura, 2010). Kubo et al. (2005)) identified plant-specific transcription factors vascularrelated NAC-Domain transcription factors VND6 and VND7. These proteins can induce transdifferentiation of various types of cells into metaxylem and protoxylem-like vessel elements, respectively. The functional suppression of VND6 and VND7 causes defects in the formation of vessel elements (Kubo et al. 2005; Yamaguchi et al., 2008). Subsequently, Ohashi-Ito et al. (2010) found that VND6 is a direct regulator of genes related to programmed cell death as well as to secondary wall formation. These results strongly suggest that VND6 and VND7 act as key regulators of xylem vessel differentiation. Recently, it has been reported that VND-INTERACTING2, isolated as an interacting factor with VND7 protein, negatively regulates xylem vessel differentiation (Yamaguchi et al., 2010).

\section{Tracheary element differentiation using Zinnia elegans mesophyll cells}

Since the 1980s, the Zinnia elegans mesophyll cell culture system has been used extensively as a tool to study xylogenesis in vitro. It has provided data on the diverse morphological, structural, biochemical and molecular events that occur during TE formation, including the hormonal regulation of TE differentiation (Fukuda 2004). The system for generating $Z$. elegans single mesophyll cell cultures is simple and well-defined: the first appearing pair of leaves of Zinnia elegans plantlets is mixed with mannitol and the mixture ground gently in a mortar and pestle or using a blender. Steps for mechanical isolation and culture of mesophyll cells are described in detail by Kärkönen et al. (2011). An adaptation of the process of TE differentiation in the $Z$. elegans xylogenic culture is presented in Figure 2. Zinnia elegans leaf cells are easily isolated intact because these cells have very few points of contact with each other (McCann et al. 2000). Single mesophyll cells from Zinnia elegans contain both palisade and spongy parenchyma cells approximately $50 \mu \mathrm{m}$ long and $25 \mu \mathrm{m}$ wide. Isolated and intact mesophyll cells can subsequently be triggered to differentiate into TEs in a modified Fukuda and Komamine medium supplemented with auxin and cytokinin. Tracheary element differentiation usually occurred within three days of the initial hormonal stimulus. The differentiated TEs were 70 to $100 \mu \mathrm{m}$ in length and 30 to $60 \mu \mathrm{m}$ in width, indicating that the cells had expanded during culture (Fukuda and Komamine 1980b). Single mesophyll cells of $Z$. elegans differentiated directly into TEs without prior cell division. Studying biochemical markers of TE differentiation, Fukuda and Komamine (1982) demonstrated that phenylalanine ammonia-lyase and peroxidase bound to the cell walls can be used as marker proteins for the differentiation of TE and lignin biosynthesis. The same authors reported an synchronous in vitro differentiation of $Z$. elegans mesophyll cells into TEs with a differentiation rate of up to $60 \%$ (Fukuda and Komamine 1980a) (Table 1). Kohlenbach and Schöpke (1981) showed that isolated single mesophyll protoplasts of $Z$. elegans can differentiate into TEs without cell 
division using Fukuda and Komamine medium supplemented with $1 \mathrm{mg} \mathrm{L}^{-1}$ BAP and $2 \mathrm{mg} \mathrm{L}^{-1}$ NAA. TE formation occurred after five days on induction medium using protoplasts originating from primary leaves. The differentiation rate for Zinnia elegans TEs ranges from 30\% to $80 \%$ synchronously (Table 1, Fukuda \& Komamine 1980b, Roberts \& McCann 2000). Roberts et al. (1992) developed a simplified medium for the differentiation of TEs in suspension cultures of mesophyll cells of $Z$. elegans. All inorganic salts contained in media used previously were retained in the simplified medium, but most were reduced in concentration. The only organic supplements required for optimum differentiation were thiamine and nicotinic acid, in addition to the plant growth regulators BAP and NAA and sucrose as a carbon source. Mannitol, an osmoticum, was necessary for rapid, synchronous differentiation. Twumasi et al. (2009) also established in vitro $Z$. elegans cell suspension cultures using a differentiation medium supplemented with $1 \mathrm{mg} \mathrm{L}^{-1}$ BAP and $1 \mathrm{mg} \mathrm{L}^{-1}$ NAA. These cultures also had high TE differentiation rates (up to $76 \%$ ) mainly due to conditioning of the mesophyll cell culture and adjustments of the phytohormonal balance in the cultures. Furthermore, the authors demonstrated the association of TE differentiation with production of molecules related wound- or stress-responses. Later, Twumasi et al. (2010) demonstrated the role of caspase inhibitors on the kinetics of TE formation and dimensions of TEs in xylogenic Z. elegans cell cultures. Roberts and McCann (2000) reported that, after 96 hours, about $80 \%$ of the cells synchronously undergo differentiation. A high differentiation rate is important as it improves the usefulness of the Z. elegans system as a model for xylogenesis-related research.

Ohdaira et al. (2002) studied mechanisms related to structural changes of cell walls in TE-forming $Z$. elegans cultures. Active cell-wall degradation took place concurrently with secondary cell-wall formation in developing TEs, with pectin being one of the most substantially modified cell-wall fractions. Lacayo et al. investigated the cell-wall composition and structure of single Z. elegans TEs. They proposed an architectural model of Zinnia elegans TEs composed of three layers: an outermost granular layer, a middle primary wall composed of a meshwork of cellulose fibrils, and inner secondary wall thickenings containing parallel cellulose microfibrils (Lacayo et al. 2010. Lignin displayed a granular shape in the secondary wall thickenings of Zinnia TEs. The loss of lignin, observed by synchrotron radiation-based Fourier-transform infrared spectromicroscopy, correlated well with the absence of granules from chemically treated secondary wall fragments. Pesquet et al. (2013) showed that living, parenchymatic xylem cells contribute to TE lignification in a non-cell-autonomous manner, thus enabling the postmortem lignification of TEs.
The Zinnia elegans TE system has been used by several authors to investigate the role of various experimental factors influencing TE differentiation. Initial cell density is a determining factor in TE differentiation in Z. elegans mesophyll cell cultures (Fukuda and Komamine 1980b). Kohlenbach and Schöpke (1981) showed that $Z$. elegans protoplasts isolated from cotyledons differentiated into TEs later and to a lesser degree than protoplasts originating from primary leaves. The competence to differentiate is highly dependent on $Z$. elegans cell concentration. Tracheary element differentiation occurs synchronously at high frequency above initial cell densities of $4.2 \times 10^{4}$ cells $\mathrm{mL} \mathrm{L}^{-1}$, but is significantly suppressed below this threshold. This result indicates that intercellular interactions are involved in the initiation and/or subsequent progresses in TE differentiation (Matsubayashi et al. 1999). McCann et al. (2000) reported that plant condition and leaf age are critical factors influencing TE differentiation in the Zinnia elegans in vitro system. Demura et al. (2002) constructed a comprehensive profile of gene expression in an in vitro Zinnia culture system to gather fundamental information about the gene regulation underlying the differentiation of plant cells. Together, Ito and Fukuda (2002) demonstrated that Zinnia elegans endonuclease 1 (ZEN1) is a key enzyme in the degradation of nuclear DNA during programmed cell death of TEs. Reactive oxygen species, such as hydrogen peroxide, are important signalling compounds in various cell death processes in plants. Gabaldón et al. (2005) demonstrated that Nitric oxide (NO) production was necessary for differentiation of TEs derived from $Z$. elegans mesophyll cells. Nitric oxide formation was sustained during secondary cell-wall synthesis and cell autolysis. Gómez Ros et al. (2006) demonstrated that differentiating Zinnia elegans cultures are capable of producing reactive oxygen species in vitro. Twumasi et al. (2009) indicated the importance of initial cell viability for TE differentiation Cultures with an initial cell viability below $40 \%$ either formed only low numbers or no TEs. Kwon et al. suggested that the protein RabG3b plays a role in TE differentiation through its function in autophagy Kwon et al. (2010). Pesquet et al. (2010) established the role of microtubule bundling in setting up the corresponding pattern of secondary cell wall thickenings. Pesquet and Tuominen (2011) demonstrated the strict dependence of TE differentiation on ethylene biosynthesis and a stimulatory effect of ethylene on the rate of TE differentiation in vitro. Sato et al. (2011) compared TE lignification and the formation of stress-induced, lignin-like substances using the Z. elegans in vitro system to understand their mechanism of formation. The authors suggested that in the Z. elegans lignin formation in TEs is regulated by the localisation and activity levels of peroxidases. 
The Zinnia system is a robust model for vascular development in plants providing a set of stage-specific marker genes for xylogenesis (Milioni et al. 2002; Pesquet et al. 2005). However, the major limitation of the Zinnia elegans system is that the initiation of xylogenic cultures is exclusively done from freshly isolated mesophyll.

\section{In vitro tracheary element systems of other herbaceous angiosperms}

A study by Fosket and Torrey (1969) reported that the TE differentiation rate of Glycine max var. Biloxi ranged from 0 to $9 \%$. Tracheary element differentiation occurred in all phases of callus growth. Both the number of TEs and the number of cells increased logarithmically, demonstrating that TE formation was correlated to cell division. Aloni (1980) studied the roles of auxin and sucrose on TE differentiation in callus cultures of Daucus carota L., Syringa vulgaris L. and Glycine max (L.) Merr. They found that the average TE cell count per callus observed in this study was up to 36, 56 and 93 for Syringa, Daucus and Glycine cultures, respectively (Table 1). The authors did not state the size of the callus.

\section{In vitro tracheary element systems in wood-forming angiosperm and gymnosperm species}

Herbaceous in vitro TE systems have contributed significantly to the understanding of xylogenesis. However, it is important to have long-lived woody trees species included as model plants to study xylogenesis, as TE differentiation may differ between herbaceous and woody plants.

In vitro tracheary element systems with angiosperm trees As far as the authors are aware, the only angiosperm tree species used to experimentally produce TEs in vitro belongs to the genus Populus. The major advantages of using Populus spp. as model systems are their economic importance as a forestry species, their relatively small genomic size of $5.5 \times 10^{8}$ base pairs (Pillai et al. 2011), and their ability to be genetically transformed. Ohlsson et al. (2006) established two cell suspension cultures to investigate the function of enzymes involved in cell wall biosynthesis in the hybrid aspen, Populus tremula $x P$. tremuloides. The cultures were characterised by the enzymatic activities and/or mRNA expression levels of cell wall-specific proteins at different stages of cell suspension growth. The fine suspension culture was grown in darkness, and consisted of relatively homogeneous small yellowish aggregates. Subsequently, slow growing aggregates were transferred to light and used to establish a granular suspension culture, containing yellowish aggregates of different sizes, up to $10 \mathrm{~mm}$ in diameter. The authors reported the formation of TEs in the stationary growth phase of the cell suspension cultures, particularly in the granular culture. They also demonstrated that cell suspension cultures of hybrid poplar exhibited a high level of gene expression for cellulose synthase coinciding with increased cellulose synthase activity. Yamagishi et al. (2013) reported the formation of TEs in calli derived from petioles of hybrid poplar (Populus sieboldii $x$ P. grandidentata) after 10 days of culture on medium containing $1 \mu \mathrm{M}$ brassinolide. The TEs that developed in calli were formed within cell clusters.

Ogita et al. (2012) established a xylogenic suspension culture system using a Phyllostachys species of bamboo, and identified that the most common inter-unit linkages in the bamboo cultured cell lignin were $\beta$-aryl ether, phenylcoumaran and resinol structures.

\section{In vitro tracheary element systems with gymnosperm trees}

Tracheary element systems were established in species from the genera Cryptomeria, Sequoia, Ginkgo, Cupressus, Pseudostuga, Pinus and Picea (reviewed by Möller 2006), to study TE formation and secondary cell-wall formation in gymnosperms.

Webb (1981) observed the formation of TEs in Pinus contorta (Douglas) suspension cultures in a medium supplemented with $1 \mathrm{mg} \mathrm{L}^{-1}$ 2,4-D and $1 \mathrm{mg} \mathrm{L}^{-1} \mathrm{kin}$ etin. Tracheary element differentiation was highest, ranging from 20 to $40 \%$ of the cells, directly after the initiation of suspension cultures, and declined with the duration of culture to 5 to $10 \%$ of the cells (duration of culture unspecified).

Around the same time, Makino et al. (1983) investigated the formation of TEs in calli on Cryptomeria japonica D. Don and Sequoia sempervirens shoot and Ginkgo biloba petiole segments cultured on solid Saito's inorganic medium Saito (1980) with the amino acids, $10 \mathrm{mg} \mathrm{L}^{-1}$ indolebutyric acid and $0.02 \mathrm{mg} \mathrm{L}^{-1}$ kinetin (Makino et al. 1983). A few years later, Ramsden and Northcote (1987) found that TEs could be induced when Pinus sylvestris L. suspension cultures were transferred from PRL-4 maintenance medium containing $2 \%$ sucrose, $2 \mathrm{mg} \mathrm{L}^{-1} \mathrm{NAA}$ and $2 \mathrm{mg} \mathrm{L}^{-1}$ 2,4-D to the same basal medium supplemented with $6 \%$ sucrose, $10 \mathrm{mg} \mathrm{L}^{-1}$ NAA and $2 \mathrm{mg} \mathrm{L}^{-1}$ kinetin. The TE differentiation was $16 \%$ after 25 days culture in the latter medium. Secondary thickening of the wall of cells cultured in the induction medium was confirmed by microscopic examination and correlated with an increase in the lignin content and changes in the polysaccharide composition of the cell wall. Pinus sylvestris suspension cultures retained their ability to form TEs after transfer to induction medium even after 40 subcultures that spanned 2 years (Ramsden and Northcote 1987). Havel et al. (1997) induced TEs formation in friable callus cultures initiated from zygotic embryos in 
Cupressus sempervirens. The average number of TEs per cluster was 30 (Table 1). The authors did not indicate the size of the callus, however. Single cells represented approximately $30 \%$ of the total cell population, and cell clusters $70 \%$. No free single TEs were found but TEs were formed in $~ 2.5 \%$ of all clusters.

Möller et al. (2003) found that Pinus radiata xylem strips-derived callus cells maintained on $\mathrm{P} 6-\mathrm{SHv}$ medium (Hotter 1997) supplemented with $4.5 \mu \mathrm{M}$ 2,4-D and 4.4 $\mu \mathrm{M}$ BAP differentiated into TEs when transferred to P6-SHv medium supplemented with $2 \mathrm{~g} \mathrm{~L}^{-1}$ activated charcoal. The differentiation rate varied from $2 \%$ to $45 \%$ depending on growth conditions. High differentiation rates were observed when calli were grown on solid modified EDM medium containing $5 \mathrm{~g} \mathrm{~L}^{-1}$ activated charcoal without phytohormones and exposed to light (Möller et al. 2006). Exposure to light was found to increase the proportion of TEs differentiating in $P$. radiata callus cultures placed on induction medium. The differentiation rate increased from $20 \%$ when calli were grown in darkness to $45 \%$ when calli were grown with $16 \mathrm{~h}$ or $24 \mathrm{~h}$ of light exposure. When callus was grown with a $16 \mathrm{~h}$ photoperiod, TEs were observed 2 days after transfer of calli to the induction medium, as compared to 5 days when calli were cultured in darkness (Möller et al. 2006). The authors showed that Pinus radiata TEs start to differentiate at different times (asynchrony) after transfer of the cells to induction medium. One possible explanation may be that $P$. radiata callus cells transferred to induction medium were in different stages of the cell cycle. The authors hypothesised that the callus cells were more responsive to TE inducing signals in a specific phase of the cell cycle, as this is the case in mesophyll cell suspension cultures of Zinnia elegans, which were highly responsive in the early S-phase (Mourelatou et al. 2004). The differentiation rates observed with xylogenic cell lines initiated from 18 different genotypes of $P$. radiata varied from 10\% to $40 \%$ after $16 \mathrm{~h}$ of light exposure. The rates varied not only between genotypes but also between explant types (root, hypocotyl, cotyledon and needle) isolated from the same plant (Devillard, unpublished). Xylogenic $P$. radiata cell lines can be maintained on P6-SHv medium (Hotter 1997) supplemented with $4.5 \mu \mathrm{M}$ 2,4-D and 4.4 $\mu \mathrm{M}$ BAP. However, in vitro P. radiata xylogenic cell cultures lose their capacity to proliferate and form TEs with prolonged in vitro culture periods (Devillard, unpublished).

Tracheary element differentiation in Pseudostuga menziesii was reported by Pillai et al. (2011). Callus cells were initiated on cambial strips obtained from 4 to 8 year-old trees and cultured on solidified Murashige and Skoog medium (Murashige and Skoog 1962) supplemented with 2,4-dichlorophenoxyacetic acid (2,4-D) and benzylaminopurine. Tracheary element formation was induced when calli were subcultured several times on maintenance medium and subsequently transferred to solidified Murashige and Skoog medium (Murashige and Skoog 1962) supplemented with $4 \mathrm{~g} \mathrm{~L}^{-1}$ activated charcoal. The percentage of TEs differentiating after 6-7 weeks on solid medium was not reported. Remarkably, approximately $65 \%$ of the callus cells differentiated into TE-like cells provided they were cultured on a liquid version of the same initiation medium excluding benzylaminopurine for 6-7 weeks without subculture. 2,4-Dichlorophenoxyacetic acid was the only phytohormone was essential for in vitro TE differentiation of $P$. menziesii suspension cultured cells. Unlike the TEs formed on solidified medium, most of the cells in suspension cultures divided end to end, forming strands of about five to six or more cells.

\section{Tracheary elements and genetic transformation}

Xylogenic lines can be genetically transformed prior to TE differentiation. Three common methods used to transform xylogenic lines are biolistic particle delivery (Ito and Fukuda 2002; Möller et al. 2003; Wagner et al. 2012), Agrobacterium tumefaciens-mediated transformation (Pyo et al. 2007; Pesquet et al. 2010; Ohashi-Ito et al. 2010) and electroporation (Endo et al. 2008).

A number of xylogenic cultures have been transformed using biolistic techniques. Ito and Fukuda (2002) achieved the transformation of cultured $Z$. elegans cells with the $Z$. elegans endonuclease 1 (ZEN1) gene using a particle bombardment method. Pinus radiata xylogenic cell cultures can be transformed biolistically using a particle gun and subsequently used for testing of genes related to cell differentiation and cell-wall formation (Möller et al. 2003; Wagner et al. 2012). This cell culture system is very useful for functional genomics as it allows silencing and over-expression of candidate genes. A maintenance protocol is available for transgenic xylogenic $P$. radiata cell lines. Producing transgenic TE lines is generally much faster than production of transgenic plants, which makes TE systems faster and more economic for studying the effects of genes on xylogenesis (Möller et al. 2003; Pillai et al. 2011; Wagner et al. 2011; Wagner et al. 2013). The in vitro radiata pine $\mathrm{TE}$ cell culture system requires minimal space. Furthermore, the production of nontransgenic and transgenic xylogenic cell cultures for repeated testing is fast and independent of season (Möller 2006).

Oda et al. (2005) developed an in vitro Arabidopsis thaliana TE system using a newly established transgenic cell suspension, named AC-GT13 and based on Agrobacterium tumefaciens-mediated transformation with a green fluorescent protein containing vector. The cell suspension was derived from A. thaliana (Columbia) root culture with auxin and cytokinin (Mathur et al. 1998). Oda et al. (2005) demonstrated that the genetically transformed $A$. thaliana suspensions could be induced to 
form TEs. The induction medium consisted of a modified Murashige and Skoog (Murashige and Skoog 1962) medium containing $1 \mu \mathrm{M}$ brassinolide. Suspension cultures were maintained in the dark. Instead of auxin and cytokinin, AC-GT13 cells required brassinosteroid for TE differentiation, with 2,4-dichlorophenoxyacetic acid (2,4-D) having an inhibitory effect on TE differentiation. Tracheary elements were semi-synchronously formed during 48 to $96 \mathrm{~h}$ of culture, with more than $30 \%$ of the cells differentiating into TEs (Table 1). Interestingly, the TEs developed in a congregated manner on the inside of cell clumps. It was also found that lowering sucrose (1\% vs. $3 \%)$ and phosphate $\left(170 \mathrm{mg} \mathrm{L}^{-1}\right.$ vs. $\left.510 \mathrm{mg} \mathrm{L}^{-1}\right)$ concentrations in the medium resulted in finer cell clumps that were suitable for microscopic observations. Using this system, the authors were able to demonstrate the participation of cortical microtubules in the deposition of patterned secondary walls during TE differentiation (Oda et al. 2005). Pyo et al. (2007) used Agrobacterium tumefaciens-mediated transformation to study the regulation of programmed cell death-related gene expression. They discovered a novel tracheary-element-regulating ciselement (TERE), which is responsible for expression of both secondary wall-related and PCD-related genes.

Transient transformation and gene silencing was performed by Endo et al. (2008) in Zinnia elegans cell cultures differentiating TEs. They used an electroporation based method to introduce plasmid DNA/double-stranded RNAs into freshly isolated $Z$. elegans mesophyll cells. This method allowed: (i) subcellular targeting of proteins in differentiating $Z$. elegans cells; (ii) co-expression of several reporter genes; (iii) promoter activity monitoring; and (iv) gene silencing by the direct introduction of doublestranded RNAs. Genes encoding the catalytic subunit of cellulose synthase, CesA, were efficiently silenced by introduction of CesA double stranded RNA molecules. This resulted in an increase of abnormal TEs with aberrant secondary walls and confirmed the guiding role of cellulose deposition on lignification.

\section{Tracheary elements in vitro and in planta}

Tracheary elements often differentiate in vitro as single cells or in random groups and do not form complete vascular tissue, such as wood. Therefore, vascular function and polar organisation cannot be addressed in tissue cultures (Church 1993). Also, seasonal processes, such as earlywood, latewood formation, and heartwood formation and the seasonal cycle of cambial dormancyactivity, probably cannot be studied in in vitro cell cultures (Chaffey 2002; Möller 2006).

In planta, all stages of differentiation are present in the same tissue, as opposed to the in vitro synchronous cell culture systems where at any given time only TEs of the same differentiation stage are present. This is a limitation when suggesting an in planta model from an in vitro one. On the other hand, synchrony of TE formation is an advantage when studying TE differentiation. (Lacayo et al. 2010). In planta, xylem precursor cells derived from the cambium in a process that can be defined as a "continuous cambium". By contrast, the in vitro TE differentiation system, in which all cells progress sequentially towards TE differentiation, can be defined as a "discontinuous cambium”. Discontinuous cambium models can reveal characteristics of the individual stages of TE differentiation in a unique manner, but they are not directly comparable to a continuous cambium (Pesquet et al. 2011).

Identical hormonal signals induce TE differentiation of Zinnia mesophyll cells in in vitro cell cultures and in leaf discs, in which positional relationships and contact between cells of the mesophyll and vasculature are maintained (Church 1993). Xylogen, a proteoglycan-like factor accumulates in vascular tissues and mediates cell-cell interactions required for xylem differentiation in Zinnia cells cultured in vitro (Motose et al. 2004). The cell-wall lignin content and composition in in vitro differentiated TEs is similar to those produced in Pinus radiata wood, demonstrating that the in vitro $P$. radiata TE system is well suited to study the formation of lignified secondary cell walls in gymnosperms (Möller et al. 2005a; Wagner et al. 2007). In vitro cultured Zinnia elegans mesophyll cells are a single cell-based system so cannot be used to study cellto-cell communication that is occurring during xylogenesis in plants. Furthermore, because Z. elegans TEs develop in vitro as single cells rather than in contact with neighbouring cells, their outermost surfaces may not be representative of structures in living plants (Pesquet et al. 2006; Lacayo et al. 2010). Ogita et al. (2012) found several differences in bamboo lignin substructures between in vitro cultured cells and milled wood. Therefore, the authors stated that the Phyllostachys bamboo in vitro TE system could be a powerful tool for exploring the dynamics of the lignification process of bamboo. Yamagishi et al. (2013) reported that in vitro induced TEs formed bordered pits and broad regions of secondary wall thickening resembling TEs of secondary xylem in hybrid poplar (Populus sieboldii $x$ P. grandidentata). Pesquet et al. (2013) showed that TE lignification occurs after TE programmed cell death in in vitro TEs and in planta.

\section{Current issues and future challenges}

Technical challenges that need to be overcome for some in vitro TE systems include:

- Selection of xylogenic cell cultures with high growth, transformation and TE differentiation rates

- Cryopreservation protocols for xylogenic cell cultures

- Synchronisation of TE differentiation 
- Development of in vitro TE culture systems for new plant species

Understanding the process of TE differentiation and its regulation requires the identification of key components (genes, transcription factors, intracellular and exogenous signalling molecules) involved in these processes followed by understanding their interactions and regulation. In vitro TE cell cultures will be a very useful tool to further study TE formation by integrating genomic, transcriptomic, proteomic and metabolomic data during TE differentiation. The role of the extracellular matrix and plant cell-to-cell communication (Hirakawa et al. 2011) must also be investigated to determine whether some cells may be required to remain as "xylem parenchyma cells" to act as nurse or feeder cells during in vitro TE differentiation.

\section{Conclusion}

When used as models, in vitro TE culture systems can contribute to a better understanding of wood formation and have advantages over in planta systems, both for basic scientific and more applied studies. The process of TE differentiation including secondary cell wall formation, lignification and programmed cell death, will be better understood by employing in vitro cell culture approaches. Responses of in vitro TE systems to enzymatic and microbial degradation could provide knowledge assisting in biofuel production from lignocellulosic biomass (Lacayo et al. 2010). This work will help refine current cambium models, both the in vitro discontinuous and in planta continuous model (Pesquet and Tuominen 2011). Finally, further analysis using in vitro TE systems could help provide additional insight into stress-responses and the complex mechanisms of lignin formation during xylem differentiation (Pesquet et al. 2010; Sato et al. 2011; Wagner et al. 2011). New genomic technologies are well suited to identify the basic biological networks underlying cambial functions and wood formation (Fenning and Gershenzon 2002; Fenning et al. 2008; Du and Groover 2010;Groover 2007). An increasing basic knowledge of secondary vascular plant growth and development of trees using TE in vitro culture systems may contribute to practical applications addressing bioenergy demands, deforestation, and climate change issues.

\section{Abbreviations}

2,4 D: 2,4-dichlorophenoxyacetic acid; BAP: 6-benzyl-aminopurine; EDM: Embryo development medium; IAA: Indole-3- acetic acid; IPAR: Isopentenyl adenine riboside; NAA: Naphthaleneacetic acid; PCD: Programmed cell death; TE: Tracheary element;

DNase: Desoxyribonuclease; RNase: Ribonuclease.

\section{Competing interests}

The authors declare that they have no competing interests.

\section{Authors' contributions}

CD drafted and edited the manuscript (90\%) and CW discussed and reviewed the manuscript (10\%). All authors read and approved the final manuscript.

\section{Acknowledgements}

We are grateful for improvements made to the manuscript by Armin Wagner, Mike Menzies, two anonymous reviewers and the editors of the New Zealand Journal of Forestry Science. Funding for this review was provided by Scion.

\section{Author details}

${ }^{1}$ Weka Street, Rotorua New Zealand. ${ }^{2} 12$ Calder Road Lake Okareka, Rotorua 3076, New Zealand.

Received: 17 September 2013 Accepted: 3 September 2014 Published online: 18 October 2014

\section{References}

Ahuja, MR, \& Neale, DB. (2005). Evolution of genome size in conifers. Silvae Genetica, 54(3), 126-137.

Aloni, R. (1980). Role of auxin and sucrose in the differentiation of sieve and tracheary elements in plant tissue cultures. Planta, 150(3), 255-263.

Arabidopsis Genome Initiative. (2000). Analysis of the genome sequence of the flowering plant Arabidopsis thaliana. Nature, 408(6814), 796.

Boerjan, W, Ralph, J, \& Baucher, M. (2003). Lignin biosynthesis. Annual Review of Plant Biology, 54(1), 519-546.

Bollhöner, B, Prestele, J, \& Tuominen, H. (2012). Xylem cell death: emerging understanding of regulation and function. Journal of Experimental Botany, 63(3), 1081-1094.

Chaffey, N. (2002). Why is there so little research into the cell biology of the secondary vascular system of trees? New Phytologist, 153(2), 213-223.

Church, DL. (1993). Tracheary element differentiation in Zinnia mesophyll cell cultures. Plant Growth Regulation, 12(3), 179-188.

Church, DL, \& Galston, AW. (1988). Kinetics of determination in the differentiation of isolated mesophyll cells of Zinnia elegans to tracheary elements. Plant Physiology, 88, 92-96.

Demura, T, \& Fukuda, H. (2007). Transcriptional regulation in wood formation. Trends Plant Sci, 12, 64-70.

Demura, T, Tashiro, G, Horiguchi, G, Kishimoto, N, Kubo, M, Matsuoka, N, Minami, A, Nagata-Hiwatashi, M, Nakamura, K, Okamura, Y, Sassa, M, Suzuki, S, Yazaki, J, Kikuchi, S, \& Fukuda, H. (2002). Visualization by comprehensive microarray analysis of gene expression programs during transdifferentiation of mesophyll cells into xylem cells. Proceedings of the National Academy of Sciences of the United States of America, 99(24), 15794-15799.

Denton, D, Nicolson, S, \& Kumar, S. (2012). Cell death by autophagy: facts and apparent artefacts. Cell Death and Differentiation, 19(1), 87-95.

Du, J, \& Groover, A. (2010). Transcriptional regulation of secondary growth and wood formation. Journal of Integrative Plant Biology, 52(1), 17-27.

Endo, S, Pesquet, E, Tashiro, G, Kuriyama, H, Goffner, D, Fukuda, H, \& Demura, T. (2008). Transient transformation and RNA silencing in Zinnia tracheary element differentiating cell cultures (Plant Journal (2007) 53, (864-875)). Plant Journal, 54(5), 964.

Endo, S, Pesquet, E, Yamaguchi, M, Tashiro, G, Sato, M, Toyooka, K, Nishikubo, N, Udagawa-Motose, M, Kubo, M, Fukuda, H, \& Demura, T. (2009). Identifying new components participating in the secondary cell wall formation of vessel elements in Zinnia and Arabidopsis. Plant Cell, 21(4), 1155-1165.

Fenning, TM, \& Gershenzon, J. (2002). Where will the wood come from? Plantation forests and the role of biotechnology. Trends in Biotechnology, 20(7), 291-296.

Fenning, TM, Walter, C, \& Gartland, KMA. (2008). Forest biotech and climate change. Nature Biotechnology, 26(6), 615-617.

Fosket, DE, \& Torrey, JG. (1969). Hormonal control of cell proliferation and xylem differentiation in cultured tissues of glycine max var, Biloxi. Plant Physiology, 44(6), 871-873. 875-880.

Fukuda, H. (1992). Tracheary element formation as a model system of cell differentiation. International Review of Cytology, 136, 289-332.

Fukuda, H. (1996). Xylogenesis: initiation, progression, and cell death. Annual Review of Plant Physiology and Plant Molecular Biology, 47(1), 299-325.

Fukuda, H. (1997a). Programmed cell death during vascular system formation. Cell Death and Differentiation, 4(8), 684-688. 
Fukuda, H. (1997b). Tracheary element differentiation. Plant Cell, 9(7), 1147-1156. Fukuda, H. (2000). Programmed cell death of tracheary elements as a paradigm in plants. Plant Molecular Biology, 44(3), 245-253.

Fukuda, H. (2004). Signals that control plant vascular cell differentiation. Nature Reviews Molecular Cell Biology, 5(5), 379-391.

Fukuda, H. (2010). Plant tracheary elements. Encyclopedia of Life Sciences, 1-5. doi:10.1002/9780470015902.a0001814.pub2.

Fukuda, H, \& Komamine, A. (1980a). Direct evidence for cytodifferentiation to tracheary elements without intervening mitosis in a culture of single cells isolated from the mesophyll of Zinnia elegans. Plant Physiology, 65(1), 61.

Fukuda, H, \& Komamine, A. (1980b). Establishment of an experimental system for the study of tracheary element differentiation from single cells isolated from the mesophyll of Zinnia elegans. Plant Physiology, 65(1), 57-60.

Fukuda, H, \& Komamine, A. (1982). Lignin synthesis and its related enzymes as markers of tracheary-element differentiation in single cells isolated from the mesophyll of Zinnia elegans. Planta, 155(5), 423-430. doi:10.1007/bf00394471.

Gabaldón, C, Gómez Ros, LV, Pedreño, MA, \& Barceló, AR. (2005). Nitric oxide production by the differentiating xylem of Zinnia elegans. New Phytologist, 165(1), 121-130.

Gómez Ros, LV, Paradiso, A, Gabaldón, C, Pedreño, MA, De Gara, L, \& Ros Barceló, A. (2006). Two distinct cell sources of $\mathrm{H}_{2} \mathrm{O}_{2}$ in the lignifying Zinnia elegans cell culture system. Protoplasma, 227(2-4), 175-183.

Groover, AT. (2007). Will genomics guide a greener forest biotech? Trends in Plant Science, 12(6), 234-238.

Groover, A, DeWitt, N, Heidel, A, \& Jones, A. (1997). Programmed cell death of plant tracheary elements differentiating in vitro. Protoplasma, 196(3-4), 197-211.

Hara-Nishimura, I, \& Hatsugai, N. (2011). The role of vacuole in plant cell death. Cell Death \& Differentiation, 18(8), 1298-1304.

Havel, L, Scarano, MT, \& Durzan, DJ. (1997). Xylogenesis in Cupressus callus involves apoptosis. Advances in Horticultural Science, 11(1), 37-40.

Hirakawa, Y, Kondo, Y, \& Fukuda, H. (2011). Establishment and maintenance of vascular cell communities through local signaling. Current Opinion in Plant Biology, 14(1), 17-23.

Höfte, H. (2010). Plant cell biology: how to pattern a wall. Current Biology, 20(10), R450-R452.

Hotter, GS. (1997). Elicitor-induced oxidative burst and phenylpropanoid metabolism in Pinus radiata cell suspension cultures. Australian Journal of Plant Physiology, 24(6), 797-804.

Ito, J, \& Fukuda, H. (2002). ZEN1 is a key enzyme in the degradation of nuclear DNA during programmed cell death of tracheary elements. Plant Cell, 14(12), 3201-3211.

Ito, Y, Ino, R, Yoshida, S, \& Fukuda, H. (2004). Establishment of a new Zinnia experimental system including separation of the distinct cell population with flow cytometry and its culture. Plant Biotechnology, 21(2), 103-108.

Ito, Y, Nakanomyo, I, Motose, H, Iwamoto, K, Sawa, S, Dohmae, N, \& Fukuda, H. (2006). Dodeca-CLE as peptides as suppressors of plant stem cell differentiation. Science, 313(5788), 842-845.

Kärkönen, A, Santanen, A, Iwamoto, K, \& Fukuda, H. (2011). Plant Tissue Cultures. In ZA Popper (Ed.), Methods in Molecular Biology (Vol. 715, pp. 1-20). Clifton, N.J: Springer.

Kohlenbach, HW, \& Schöpke, C. (1981). Cytodifferentiation to tracheary elements from isolated mesophyll protoplasts of Zinnia elegans. Naturwissenschaften, 68, 576-577.

Kubo, M, Udagawa, M, Nishikubo, N, Horiguchi, G, Yamaguchi, M, Ito, J, Mimura, T, Fukuda, H, \& Demura, T. (2005). Transcription switches for protoxylem and metaxylem vessel formation. Genes \& Development, 19(16), 1855-1860

Kuriyama, H, \& Fukuda, H. (2002). Developmental programmed cell death in plants. Current Opinion in Plant Biology, 5(6), 568-573.

Kwon, SI, Cho, HJ, Jung, JH, Yoshimoto, K, Shirasu, K, \& Park, OK. (2010). The Rab GTPase RabG3b functions in autophagy and contributes to tracheary element differentiation in Arabidopsis. The Plant Journal, 64(1), 151-164.

Lacayo, Cl, Malkin, AJ, Holman, HYN, Chen, L, Ding, SY, Hwang, MS, \& Thelen, MP. (2010). Imaging cell wall architecture in single Zinnia elegans tracheary elements. Plant Physiology, 154(1), 121-133.

Leitch, MA, \& Savidge, RA. (2000). Cell, Tissue and Organ Culture for the Study of Cambial Activity and Wood Formation-a Resurgence of Interest in an old Technique. In RA Savidge, JR Barnett, \& R Napier (Eds.), Cell and Molecular Biology of Wood Formation (pp. 493-512). Oxford, UK: BIOS Scientific.

Makino, R, Kuroda, H, \& Shimaji, K. (1983). Callus formation and effects of applied pressure to the cultured cambial explant of sugi (Cryptomeria japonica D. Don). Wood Research: Bulletin of the Wood Research Institute Kyoto University, 69, 1-11.
Mathur, J, Szabados, L, Schaefer, S, Grunenberg, B, Lossow, A, Jonas-Straube, E, Schell, J, Koncz, C, \& Koncz-Kalman, Z. (1998). Gene identification with sequenced T-DNA tags generated by transformation of Arabidopsis cell suspension. Plant Journal, 13(5), 707-716.

Matsubayashi, Y, Takagi, L, Omura, N, Morita, A, \& Sakagami, Y. (1999). The endogenous sulfated pentapeptide phytosulfokine-a stimulates tracheary element differentiation of isolated mesophyll cells of zinnia. Plant Physiology, 120(4), 1043-1048.

McCabe, PF, \& Leaver, CJ. (2000). Programmed cell death in cell cultures. Plant Molecular Biology, 44(3), 359-368. doi:10.1023/a:1026500810877.

McCann, MC. (1997). Tracheary element formation: Building up to a dead end. Trends in Plant Science, 2(9), 333-338.

McCann, MC, Stacey, NJ, \& Roberts, K. (2000). Targeted cell death in xylogenesis. Symposia of the Society for Experimental Biology, 52, 193-201.

Mehra, PN, \& Anand, M. (1979). Cytology of callus of Cryptomeria japonica. Physiologia Plantarum, 45(1), 127.

Milioni, D, Sado, PE, Stacey, NJ, Roberts, K, \& McCann, MC. (2002). Early gene expression associated with the commitment and differentiation of a plant tracheary element is revealed by cDNA-amplified fragment length polymorphism analysis. Plant Cell, 14(11), 2813-2824.

Möller, R. (2006). Tracheary element differentiation and secondary cell-wall formation in cell cultures of coniferous gymnosperms. New Zealand Journal of Forestry Science, 36(1), 156-171.

Möller, R, McDonald, AG, Walter, C, \& Harris, PJ. (2003). Cell differentiation, secondary cell-wall formation and transformation of callus tissue of Pinus radiata D. Don. Planta, 217(5), 736-747.

Möller, R, Koch, G, Nanayakkara, B, \& Schmitt, U. (2005a). Lignification in cell cultures of Pinus radiata: activities of enzymes and lignin topochemistry. Tree Physiology, 26(2), 201-210.

Möller, R, Steward, D, Phillips, L, Flint, H, \& Wagner, A. (2005b). Gene silencing of cinnamyl alcohol dehydrogenase in Pinus radiata callus cultures. Plant Physiology and Biochemistry, 43(12), 1061-1066.

Möller, R, Ball, RD, Henderson, AR, Modzel, G, \& Find, J. (2006). Effect of light and activated charcoal on tracheary element differentiation in callus cultures of Pinus radiata D. Don. Plant Cell, Tissue and Organ Culture, 85(2), 161-171.

Motose, H, Sugiyama, M, \& Fukuda, H. (2004). A proteoglycan mediates inductive interaction during plant vascular development. Nature, 429(6994), 873-878.

Mourelatou, M, Doonan, JH, \& McCann, MC. (2004). Transition of G1 to early S phase may be required for zinnia mesophyll cells to trans-differentiate to tracheary elements. Planta, 220(1), 172-176.

Murashige, T, \& Skoog, F. (1962). A revised medium for rapid growth and bio assays with tobacco tissue cultures. Physiologia Plantarum, 15(3), 473-497.

Obara, K, Kuriyama, H, \& Fukuda, H. (2001). Direct evidence of active and rapid nuclear degradation triggered by vacuole rupture during programmed cell death in zinnia. Plant Physiology, 125(2), 615-626.

Oda, Y, \& Fukuda, H. (2012). Secondary cell wall patterning during xylem differentiation. Current Opinion in Plant Biology, 15(1), 38-44.

Oda, Y, Mimura, T, \& Hasezawa, S. (2005). Regulation of secondary cell wall development by cortical microtubules during tracheary element differentiation in arabidopsis cell suspensions. Plant Physiology, 137(3), 1027-1036.

Ogita, S, Nomura, T, Kishimoto, T, \& Kato, Y. (2012). A novel xylogenic suspension culture model for exploring lignification in Phyllostachys bamboo. Plant Methods, 8(1), 40.

Ohashi-lto, K, Oda, Y, \& Fukuda, H. (2010). Arabidopsis vascular-related NAC-DOMAIN6 directly regulates the genes that govern programmed cell death and secondary wall formation during xylem differentiation. Plant Cell, 22(10), 3461-3473.

Ohdaira, Y, Kakegawa, K, Amino, SI, Sugiyama, M, \& Fukuda, H. (2002). Activity of cell-wall degradation associated with differentiation of isolated mesophyll cells of Zinnia elegans into tracheary elements. Planta, 215(2), 177-184.

Ohlsson, AB, Djerbi, S, Winzell, A, Bessueille, L, Ståldal, V, Li, X, Blomqvist, K, Bulone, V, Teeri, TT, \& Berglund, T. (2006). Cell suspension cultures of Populus tremula $\times$ P. tremuloides exhibit a high level of cellulose synthase gene expression that coincides with increased in vitro cellulose synthase activity. Protoplasma, 228(4), 221-229.

Pesquet, E, \& Tuominen, H. (2011). Ethylene stimulates tracheary element differentiation in Zinnia elegans cell cultures. New Phytologist, 190(1), 138-149.

Pesquet, E, Ranocha, P, Legay, S, Digonnet, C, Barbier, O, Pichon, M, \& Goffner, D. (2005). Novel markers of xylogenesis in zinnia are differentially regulated by auxin and cytokinin. Plant Physiology, 139(4), 1821-1839.

Pesquet, E, Jauneau, A, Goffner, D, \& Teixeira da Silva, JA. (2006). Zinnia elegans is an excellent model for xylogenesis: in vitro and in planta. Floriculture, ornamental and plant biotechnology, 171-178. 
Pesquet, E, Korolev, AV, Calder, G, \& Lloyd, CW. (2010). The microtubule-associated protein AtMAP70-5 regulates secondary wall patterning in arabidopsis wood cells. Current Biology, 20(8), 744-749.

Pesquet, E, Korolev, AV, Calder, G, \& Lloyd, CW. (2011). Mechanisms for shaping, orienting, positioning and patterning plant secondary cell walls. Plant Signaling and Behavior, 6(6), 843-849.

Pesquet, E, Zhang, B, Gorzsas, A, Puhakainen, T, Serk, H, Escamez, S, Barbierc, O, Gerberb, L, Courtois-Moreaua, C, Alatalod, E, Paulind, L, Kangasjärvie, J, Sundbergb, B, Goffnerc, D, \& Tuominena, H. (2013). Non-cell-autonomous postmortem lignification of tracheary elements in Zinnia elegans. Plant Cell, 25, 1314-1328. 10.1105/tpc.113.110593.

Pillai, KV, McDonald, AG, \& Wagner, FG. (2011). Developing a model system in vitro to understand tracheary element development in Douglas-fir (Pseudostuga menziesii). Maderas Ciencia y tecnología, 13(1), 3-18.

Pyo, H, Demura, T, \& Fukuda, H. (2007). TERE; a novel cis-element responsible for a coordinated expression of genes related to programmed cell death and secondary wall formation during differentiation of tracheary elements. Plant Journal, 51(6), 955-965.

Ramsden, L, \& Northcote, D. (1987). Tracheid formation in cultures of pine (Pinus sylvestris). Journal of Cell Science, 88(4), 467.

Roberts, K, \& McCann, MC. (2000). Xylogenesis: The birth of a corpse. Current Opinion in Plant Biology, 3(6), 517-522.

Roberts, AW, Koonce, LT, \& Haigler, CH. (1992). A simplified medium for in vitro tracheary element differentiation in mesophyll suspension cultures from Zinnia elegans L. Plant Cell, Tissue and Organ Culture, 28(1), 27-35.

Saito, A. (1980). Effects of growth regulators on somatic callus culture in Cryptomeria japonica. Journal of the Japanese Forestry Society, 62(1), 17-18.

Sato, Y, Watanabe, T, Komamine, A, Hibino, T, Shibata, D, Sugiyama, M, \& Fukuda, $H$. (1997). Changes in the activity and mRNA of cinnamyl alcohol dehydrogenase during tracheary element differentiation in Zinnia. Plant Physiology, 113(2), 425-430.

Sato, Y, Yajima, Y, Tokunaga, N, \& Whetten, R. (2011). Comparison between tracheary element lignin formation and extracellular lignin-like substance formation during the culture of isolated Zinnia elegans mesophyll cells. Biologia, 66(1), 88-95.

Turner, JA, Buongiorno, J, Maplesden, F, Zhu, S, Bates, S, \& Li, R. (2006). World Wood Industries Outlook, 2005-2030. In J Griffith (Ed.), Forest Research Bulletin, 230. Rotorua, New Zealand: New Zealand Forest Research Institute Ltd.

Turner, S, Gallois, P, \& Brown, D. (2007). Tracheary element differentiation. Annual Review of Plant Biology, 58, 407-433.

Twumasi, P, Schel, JHN, van leperen, W, Woltering, E, Van Kooten, O, \& Emons, AMC. (2009). Establishing in vitro Zinnia elegans cell suspension culture with high tracheary element differentiation. Cell Biology International, 33(4), 524-533.

Twumasi, P, lakimova, E, Qian, T, van leperen, W, Schel, J, Emons, A, van Kooten, O, \& Woltering, EJ. (2010). Caspase inhibitors affect the kinetics and dimensions of tracheary elements in xylogenic Zinnia (Zinnia elegans) cell cultures. BMC Plant Biology, 10(1), 162.

Wagner, A, Ralph, J, Akiyama, T, Flint, H, Phillips, L, Torr, K, Nanayakkara, B, \& Te Kiri, L. (2007). Exploring lignification in conifers by silencing hydroxycinnamoylCoA:shikimate hydroxycinnamoyltransferase in Pinus radiata. Proceedings of the National Academy of Sciences, 104(28), 11856-11861. doi:10.1073/ pnas.0701428104.

Wagner, A, Donaldson, L, Kim, H, Phillips, L, Flint, H, Steward, D, Torr, K, Koch, G, Schmitt, U, \& Ralph, J. (2009). Suppression of 4-coumarate-CoA ligase in the coniferous gymnosperm Pinus radiata. Plant Physiology, 149(1), 370-383.

Wagner, A, Tobimatsu, Y, Phillips, L, Flint, H, Torr, K, Donaldson, L, Pears, L, \& Ralph, J. (2011). CCOAOMT suppression modifies lignin composition in Pinus radiata. Plant Journal, 67(1), 119-129.

Wagner, A, Donaldson, L, \& Ralph, J. (2012). Lignification and Lignin Manipulations in Conifers. In L Jouanin \& C Lapierre (Eds.), Advances in Botanical Research (Vol. 61, pp. 37-76). London, UK: Elsevier.

Wagner, A, Tobimatsu, Y, Goeminne, G, Phillips, L, Flint, H, Steward, D, Torr, K, Donaldson, L, Boerjan, W, \& Ralph, J. (2013). Suppression of CCR impacts metabolite profile and cell wall composition in Pinus radiata tracheary elements. Plant molecular biology, 81(1-2), 105-117.

Webb, KJ. (1981). Growth and Cytodifferentiation of Cell Suspension Cultures of Pinus Contorta. In Paper Presented at the Colloque International sur la Culture in Vitro des Essences Forestières. Fontainebleau, France: IUFRO international workshop.

Weir, IE, Maddumage, R, Allan, AC, \& Ferguson, IB. (2005). Flow cytometric analysis of tracheary element differentiation in Zinnia elegans cells. Cytometry. Part A, 68(2), 81-91.
Yamagishi, Y, Yoshimoto, J, Uchiyama, H, Nabeshima, E, Nakaba, S, Watanabe, U, \& Funada, R. (2013). In vitro induction of secondary xylem-like tracheary elements in calli of hybrid poplar (Populus sieboldii $\times$ P. grandidentata). Planta, 237(4), 1179-1185.

Yamaguchi, M, \& Demura, T. (2010). Transcriptional regulation of secondary wall formation controlled by NAC domain proteins. Plant Biotechnol, 27, 237-242.

Yamaguchi, M, Kubo, M, Fukuda, H, \& Demura, T. (2008). VASCULAR-RELATED NAC-DOMAIN7 is involved in the differentiation of all types of xylem vessels in Arabidopsis roots and shoots. Plant Journal, 55, 652-664.

Yamaguchi, M, Ohtani, M, Mitsuda, N, Kubo, M, Ohme-Takagi, M, Fukuda, H, \& Demura, T. (2010). VND-INTERACTING2, a NAC domain transcription factor, negatively regulates xylem vessel formation in Arabidopsis. The Plant Cell Online, 22(4), 1249-1263.

Yamamoto, R, Demura, T, \& Fukuda, H. (1997). Brassinosteroids induce entry into the final stage of tracheary element differentiation in cultured Zinnia cells. Plant Cell Physiol, 38(8), 980-983.

Yamamoto, R, Fujioka, S, Iwamoto, K, Demura, T, Takatsuto, S, Yoshida, S, \& Fukuda, H. (2007). Co-regulation of brassinosteroid biosynthesis-related genes during xylem cell differentiation. Plant Cell Physiol, 48(1), 74-83.

doi:10.1186/s40490-014-0022-7

Cite this article as: Devillard and Walter: Formation of plant tracheary elements in vitro - a review. New Zealand Journal of Forestry Science 2014 44:22.

\section{Submit your manuscript to a SpringerOpen ${ }^{\circ}$ journal and benefit from:}

- Convenient online submission

Rigorous peer review

- Immediate publication on acceptance

- Open access: articles freely available online

- High visibility within the field

- Retaining the copyright to your article

Submit your next manuscript at springeropen.com 